\title{
The Influece of Service Quality and Intelegence Emotional to Satisfaction of Pilgrims in Lhokseuamwe and Characteristic Indivual as Moderate Variable
}

\author{
Nurmala $^{1}$, Sullaida ${ }^{1}$, Marbawi $^{1}$, Yusniar $^{1}$ and Azhar $^{1}$ \\ \{nurmala@unimal.ac.id\} \\ ${ }^{1}$ Lecturer at Universitas Malikussaleh, Indonesia
}

\begin{abstract}
The purpose of this study is to analyze the effect of service quality and emotional intelligence on the satisfaction of pilgrims in Lhokseumawe, with individual characteristics as moderating variable. Sampling of population used probability sampling. The samples of research are 200 people and data analyzed by using Structural Equation Model. Based on the reasearch conclude that service quality and emotional intelligence are influences to satisfaction of pilgrims in Lhokseumawe. While, individual characteristics do not affect to satisfaction of pilgrims in Lhokseumawe. But individual characteristics moderate of emotional intelligence on the satisfaction of pilgrimsin Lhokseumawe.
\end{abstract}

Keyword: Quality of Service, Emotional Intelligence, Individual Characteristics, and Satisfaction

\section{Introduction}

The implementation of the Hajj held by the government is carried out based on the principles of justice, professionalism, and accountability with the principle of non-profit. Hajj administration by the government aims to provide guidance, service, and protection as well as possible for pilgrims, so that pilgrims can perform their worship in accordance with the provisions of the teachings of Islam. The Government is obliged to carry out coaching, service and protection by providing administrative services, guidance on Hajj worship, accommodation, transportation, health services, security, and other matters needed by pilgrims.

Several types of Hajj services provided by the Office of the Ministry of Religion of Lhokseumawe such as the registration of Hajj by filling out the Request for Hajj Application (SPPH), online through the Integrated Hajj Computerization System (Siskohat) guided by officers, notification of departure schedules, carrying out the guidance of worship and rituals of Hajj, arrangement Haj passport, etc.

\section{Literature Review}

\subsection{Service}

Service is defined as a way or subject to help prepares or takes care of what is needed by someone. In the implementation of Hajj services is a way to help or take care of prospective pilgrims to be able to carry out the pilgrimage both when it is still in the land and in the holy land (Nurhasyim, 2004) These characteristics can be the basis for providing the best service. A 
broader understanding is conveyed by (Sutopo and Suryanto, 2003) that service is any business that enhances customer satisfaction.

\subsection{Service quality}

Service quality can be interpreted as an effort to meet consumer needs and desires as well as the accuracy of delivery in keeping up with consumer expectations (Tjiptono and Chandra, 2007). Quality of service (service quality) can be known by comparing the perceptions of consumers about the services they clearly receive / get with the services they actually expect / want for the service attributes of a company. If the service is perceived or perceived as expected, the quality of service is perceived to be good and satisfying, if the service received exceeds consumer expectations, the quality of service is perceived to be very good and quality.

\subsection{Emotional Intelligence}

(Goleman, 2003) states that emotional intelligence is more ability that a person has in self-motivation, resistance to failure, controlling emotions and delaying satisfaction, and regulating the soul. With emotional intelligence, a person can put his emotions on the right portion, have satisfaction and set his mood well

\subsection{Satisfaction}

Customer satisfaction is the level of feeling happy or disappointed by someone who appears after comparing the performance or results and what is expected, (Tjiptono and Chandra, 2007; Kotler and Kevin, 2009). So, the level of satisfaction is a function of the difference between perceived performance and expectations

\subsection{Individual Characteristics}

The most important resources in the organization are human resources, people who give their organization's energy, talent, creativity, and effort so that an organization can maintain its existence. Every human being has individual characteristics that differ from one another, (Robbins, 2007).

\subsection{Conceptual framework}

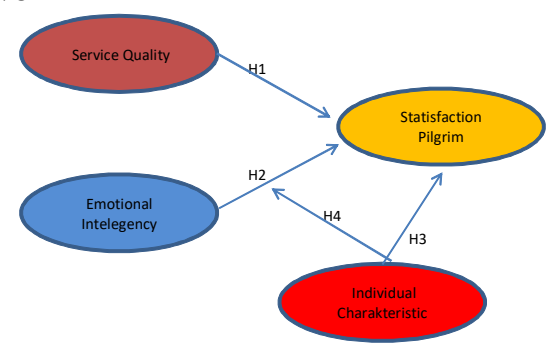

Fig.1. Conceptual Framework 


\section{Methodology}

This research was conducted at the Office of the Ministry of Religion of Lhokseumawe City which is located at Jl. Nyak Adam Kamil No.1 Kota Lhokseumawe. The object of this research is Lhokseumawe pilgrims who depart for the $2015 \mathrm{M} / 1434 \mathrm{H}$. Hajj. In this study the types and sources of data used are Primary and Secondary Data. The populations in this study all the pilgrims of Lhokseumawe City who departed in $2012 \mathrm{M} / 1433 \mathrm{H}$ totaling 241 worshipers from 4 sub-districts in the Lhokseumawe City region. Sampling in this study used probability sampling.

\section{Result And Discussion}

\subsection{Analysis of Structural Equation Modeling}

Table1. Goodness of Fit Test for Measurement Model

\begin{tabular}{|c|c|c|c|}
\hline Criteria & $\begin{array}{l}\text { Cut } \\
\text { Off }\end{array}$ & Results & $\begin{array}{l}\text { Conclusio } \\
\text { n }\end{array}$ \\
\hline Chi-Square & - & $\begin{array}{l}257.19 \\
8\end{array}$ & Good \\
\hline $\begin{array}{l}\text { The Degree } \\
\text { of Freedom }\end{array}$ & - & 129 & Good \\
\hline $\begin{array}{l}\text { The } \\
\text { Goodness of } \\
\text { Fit Index } \\
(\mathrm{GFI}) \\
\end{array}$ & $\geq 0.90$ & 0.877 & Marginal \\
\hline $\begin{array}{l}\text { Adjusted } \\
\text { Goodness of } \\
\text { Fit Index } \\
(\text { AGFI) }\end{array}$ & $\geq 0.90$ & 0.837 & Marginal \\
\hline $\begin{array}{l}\text { Tucker } \\
\text { Lewis Index } \\
(\mathrm{TLI})\end{array}$ & $\geq 0.95$ & 0.951 & Good \\
\hline $\begin{array}{l}\text { Comparative } \\
\text { Fit Index } \\
(\mathrm{CFI})\end{array}$ & $\geq 0.95$ & 0.959 & Good \\
\hline $\begin{array}{l}\text { Root Mean } \\
\text { Square Error } \\
\text { of } \\
\text { Approximati } \\
\text { on } \\
\text { (RMSEA) }\end{array}$ & $\leq 0.08$ & 0.071 & Good \\
\hline CMIN & $\leq 2.00$ & 1.994 & Good \\
\hline P-Value & $\geq 0.05$ & 0.420 & Good \\
\hline
\end{tabular}


Based on the table above, it can be seen that the suitability of the model test - goodness of fit test can be seen in the figure shows that in general all constructs used to form this research model, in the conformator factor analysis process have met the goodness of fit index criteria that have been set such as Chi value -Square, TLI and CFI, while the probability value, RMSEA, except for the GFI and AGFI values, is still smaller than required in the model, so it can be concluded that it is not fit to explain the phenomena of the research that is formed. For the next research has to modivided of model by suggested the SEM model application in the indification modification section.

\subsection{Full Model Modification}

Table2. Goodness of Fit Test for Measurement Model

\begin{tabular}{|c|c|c|c|}
\hline Criteria & $\begin{array}{l}\text { Cut } \\
\text { Off }\end{array}$ & Results & $\begin{array}{l}\text { Conclusi } \\
\text { on }\end{array}$ \\
\hline Chi-Square & - & $\begin{array}{l}188.89 \\
1\end{array}$ & Good \\
\hline $\begin{array}{l}\text { The Degree } \\
\text { of Freedom }\end{array}$ & - & 126 & Good \\
\hline $\begin{array}{l}\text { The } \\
\text { Goodness of } \\
\text { Fit Index } \\
\text { (GFI) }\end{array}$ & $\geq 0.90$ & 0.904 & Good \\
\hline $\begin{array}{l}\text { Adjusted } \\
\text { Goodness of } \\
\text { Fit Index } \\
(\text { AGFI) }\end{array}$ & $\geq 0.90$ & 0.870 & Marginal \\
\hline $\begin{array}{l}\text { Tucker } \\
\text { Lewis Index } \\
\text { (TLI) }\end{array}$ & $\geq 0.95$ & 0.975 & Good \\
\hline $\begin{array}{l}\text { Comparative } \\
\text { Fit Index } \\
\text { (CFI) }\end{array}$ & $\geq 0.95$ & 0.980 & Good \\
\hline $\begin{array}{l}\text { Root Mean } \\
\text { Square Error } \\
\text { of } \\
\text { Approximati } \\
\text { on } \\
\text { (RMSEA) }\end{array}$ & $\leq 0.08$ & 0.050 & Good \\
\hline CMIN & $\leq 2.00$ & 1.499 & Good \\
\hline P-Value & $\geq 0.05$ & 0.430 & Good \\
\hline
\end{tabular}

Based on the table seen the suitability test of the goodness of fit test model can be seen in the figure shows that in general all constructs used to form this research model, in the process of confirmatory factor analysis has fulfilled the goodness of fit index criteria that have been set such as the Chi-Square value, probability, TLI, GFI, CFI and RMSEA while the 
AGMI value is still marginal, but it is close to the required value, this means that the model is fit based on the sample data.

Thus, all variables can be measured in the proposed model. The results can be viewed in Picture 2 :

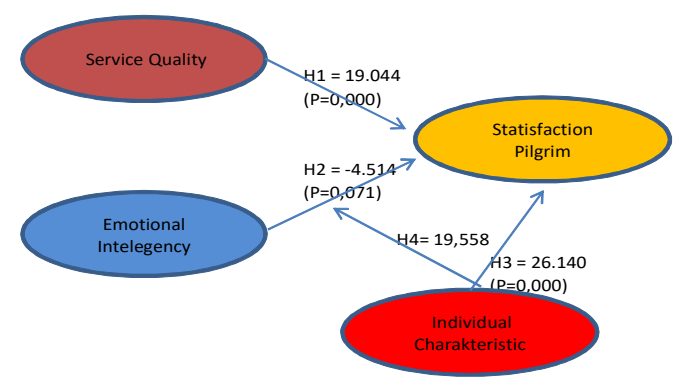

Fig. 2. Conceptual Framework

\begin{tabular}{|c|c|c|c|c|c|c|c|}
\hline & & & $\begin{array}{r}\text { Estimate } \\
\text { Unstandard } \\
\text { ized }\end{array}$ & $\begin{array}{l}\text { Estimate } \\
\text { Standardi } \\
\text { zed }\end{array}$ & SE & C.R & $\mathrm{P}$ \\
\hline Satisfaction_Jamaah & $<\ldots$ & Service_Quality & 3.227 & .885 & .201 & 19.044 & *** \\
\hline Satisfaction Jamaah & $<-\ldots$ & Individual Characteristic & -387 & -092 & 0.086 & -4.514 & $* * *$ \\
\hline Satisfaction Jamaah & $<$ & Emotional Intellegence & 3.593 & 1.005 & .137 & 26.140 & $* * * *$ \\
\hline Interaction & $<$ & Satisfaction_Jamaah & 1.000 & 1.000 & & & \\
\hline KP1 & $<$ & Service Quality & 1.000 & .788 & & & \\
\hline KP2 & $<$ & Service_Quality & .907 & .783 & .067 & 13.459 & $* * *$ \\
\hline KP3 & $<\ldots$ & Service_Quality & .889 & .810 & .063 & 14.057 & $* * *$ \\
\hline KP4 & $<-$ & Service_Quality & .880 & .817 & .062 & 14.273 & $* * *$ \\
\hline KP5 & $<\ldots$ & Service Quality & 1.012 & .782 & .076 & 13.327 & $* * *$ \\
\hline KJ1 & $<\ldots$ & Satisfaction_Jamaah & 1.000 & .560 & & & \\
\hline $\mathrm{KJ} 2$ & $<$ & Satisfaction_Jamaah & .526 & .554 & .009 & 56.297 & $* * *$ \\
\hline $\begin{array}{l}\mathrm{N} J \mathrm{~L} \\
\mathrm{KJ} 3\end{array}$ & $<$ & Satisfaction_Jamaah & .644 & .555 & .010 & 62.028 & $* * *$ \\
\hline KI1 & $<-$ & Individual_Characteristic & 1.000 & .849 & & & \\
\hline KI2 & & Individual Characteristic & 1.202 & 933 & .066 & 18.225 & $* * *$ \\
\hline KI3 & $<$ & Individual_Characteristic & 1.233 & .946 & .076 & 16.301 & $* * *$ \\
\hline KI4 & $<\ldots$ & Individual_Characteristic & 1.045 & .899 & .061 & 17.044 & $* * *$ \\
\hline KI5 & $<\ldots$ & Individual_Characteristic & .902 & .688 & .080 & 11.211 & $* * *$ \\
\hline KE1 & $<$ & Emotional_Intellegence & 1.000 & .886 & & & \\
\hline KE2 & $<-\ldots$ & Emotional Intellegence & .992 & .908 & .048 & 20.538 & $* * *$ \\
\hline KE3 & $<$ & Emotional_Intellegence & 1.014 & .912 & .049 & 20.771 & $* * *$ \\
\hline KE4 & & Emotional_Intellegence & 1.022 & .938 & .046 & 22.361 & $* * 8$ \\
\hline KE5 & $<$ & Emotional_Intellegence & 1.075 & .899 & .054 & 20.026 & $* * *$ \\
\hline & & Error & 5.872 & .722 & & & \\
\hline terak & & Intereaction & 19.558 & .692 & & & \\
\hline
\end{tabular}

Source: Data analysed (2017)

Fig. 3. Regression Weights

Based on the results of data analysis as shown in the table above can be explained as follows: 1. The coefficient value of the Emotional Intelligence variable on Individual Characteristics with a C.R value of 26.140 with a significance value of 0.000 indicates that the Emotional Intelligence variable has a significant effect on the Individual Characteristics of Lhokseumawe Hajj Pilgrims. 2. The coefficient value of Service Quality on Congregation Satisfaction with a C.R value of 19.044 and a significance value of 0.000 indicates that the Service Quality variable has a significant effect on the satisfaction of Lhokseumawe Hajj pilgrims.

The coefficient value of the Individual Characteristics variable moderates the quality of service to Congregational Satisfaction with an interaction value of 19,558 and an error value of 5,872 with these results indicating that the Individual Characteristics variable moderates the Service Quality on the Satisfaction of Lhokseumawe Hajj Pilgrims. 


\section{Conclusion}

This research finds that service quality and emotional intellegence influences on satisfaction of Lhokseumawe pilgrims. While, Individual characteristics doesnot affect on satisfaction of Lhokseumawe pilgrims. Individual characteristics moderate emotional intelligence on the satisfaction of Lhokseumawe. And suggestion to leaders of the Ministry of Religion of Lhokseumawe City in order to increase the satisfaction of pilgrims towards the services of Hajj officers, need to pay attention to and increase the attention of officers to pilgrims who need special attention, responsiveness and reliability. It is suggested to service personnel that in providing services they need to pay attention to the characteristics of the pilgrims who will be served by adjusting to the geographical conditions such as age, sex of marital status and also the personality, perception and attitude of the pilgrims to be served by placing people which is right in the direct position related to the service of pilgrims.

\section{References}

[1] Goleman, D. (2003) Kecenderungan Emosi Untuk Mencapai Puncak Emosi. Jakarta: PT Gramedia Pustaka.

[2] Kotler, P. and Kevin, K. (2009) 'Manajemen Pemasaran. Edisi Kedua Belas, PT Indeks, Jakarta'. Jakarta: Erlangga.

[3] Nurhasyim (2004) Pengembangan Model Pelayanan Haji Departemen Agama Berdasarkan Prinsip Reinventing Government yang Berorientasi Pada Pelanggan di Kabupaten Gresik. Surabaya: Program Pasca Sarjana Universitas Airlangga.

[4] Robbins, S. P. (2007) Perilaku Organisasi. Jakarta: PTMacananJaya Cemerlang.

[5] Sutopo, S. and Suryanto, A. (2003) Pelayanan Prima. Jakarta: Lembaga Administrasi Negara Republik Indonesia.

[6] Tjiptono, F. and Chandra, G. (2007) Service Quality and Satisfaction. Yogyakarta: Andi. 